\title{
Innovation procurement as key to cross-border ITS pilots
}

\author{
Ralf-Martin Soe \\ Smart City Center of Excellence (Finest Twins), \\ Tallinn University of Technology, \\ Tallinn 19086, Estonia \\ Email: ralf-martin.soe@taltech.ee
}

\begin{abstract}
Cities are criticised to be slow and rigid in adapting novel ICT-solutions. In the field of smart mobility, this can be even more complex as transport often concerns multiple regions, thus calling for more adaptive and collaboration-based models. This paper discusses how cross-border cities can initiate joint intelligent transport system (ITS) pilots via innovation procurement process. Theoretically, new public management (NPM) concept is being challenged by public value (PV) in delivering cross-border, open and experimental mobility trials. Empirically, PV and NPM models are tested via recent empirical evidence of joint ITS pilots in the cities of Helsinki, Tallinn and Vantaa as part of the finest smart mobility project.
\end{abstract}

Keywords: ITS; intelligent transport system; public procurement; ICT; information and communication technology; NPM; new public management; public value; FESM; finest smart mobility.

Reference to this paper should be made as follows: Soe, R-M. (2020) 'Innovation procurement as key to cross-border ITS pilots', Int. J. Electronic Governance, Vol. 12, No. 4, pp.387-403.

Biographical notes: Ralf-Martin Soe is a Director of Smart City Center of Excellence (Finest Twins) and Senior Research Fellow at the Tallinn University of Technology. His previous positions include being an ICT Counsellor to the Minister of Entrepreneurship and Information Technology, Supervisory Board Member at the Estonian Internet Foundation and Government Fellow at the United Nations University's e-Governemnt Unit. $\mathrm{He}$ was also an Investigative Journalist at the Business Daily Äripäev and was selected as the Best Young Journalist in Estonia by the Estonian Newspaper Association in 2008. He has two Master degrees in Financial Management (MSc, Maastricht University/United Nations University and MBA, University of Tartu) and has a PhD degree in Technology Governance from Taltech.

\section{Introduction}

This paper is interested in the interplay between innovative procurement and intelligent transport systems (ITS), especially in the case of multiple cities. There is an ongoing debate how cities and governments could apply agile and adoptive methods more widely used among business enterprises and also how public procurers can be more experimental 
(e.g., Janssen and van der Voort, 2016; Mantsinen et al., 2018; Nuottila et al., 2016; Soe and Drechsler, 2018). According to Nuottila et al. (2016) the adoption of novel methods has been slow in the public sector, although it has been implemented in the private sector (at least) since 2001, mainly for complex Information Technology system development, such as ITS. Similarly, Matthias Weber et al. (2014) analyse rapid development of information and communication technologies (ICTs) and conclude that they transform too slowly to the transport sector.

Theoretically, this project is interested in analysing the underlying concepts that drive city administrations, from the perspective of adaption of new technologies. That is, this paper questions whether the mainstream public administration theory, the new public management (NPM), can deliver novel innovations or there is a need to look for alternative theories, such as public value (PV) proposed by Moore (1995). The NPM is a mainstream theory in most western public administrations (including cities), although many scholars working with digitalisation of governments and cities, propose that this should be replaced by more adaptable and citizen-centric concepts, such as PV (e.g., Cordella and Bonina, 2012; Karunasena and Deng, 2010; Kearns, 2004; Yildiz, 2007; Yu, 2008). The key here is to analyse how cities can deliver more value through digitalisation projects. This gets even more complex when cross-border multi-city aspects are being taken into consideration, such as mobility between several cities and regions. Too often the NPM results with competing cities and city departments that work in silos; in the case of horizontal challenges, PV theory tends to works better.

Empirically, this paper is interested how cities can collaborate on establishing joint ITS services (Soe, 2017a, 2017b, 2017c) by analysing how modern ITS could be introduced in the case of two-country regional area of cities of Helsinki, Tallinn and Vantaa (Finland and Estonia). Thus, this project looks into the design and implementation of cross-border ITS pilots aiming to solve mobility challenges between these three cities. In the case of increasing cross-border mobility (mid-size capital cities of Helsinki and Tallinn have more than 8 million commutes annually), more theoretical and empirical focus should be put on mobility solutions that roam from one city to another. In such a cross-border area consisting of multiple cities, one-city solutions tend not to work in another city, which is even more crucial when looking into the challenges in the border areas, including in harbours.

\section{Literature review}

\subsection{Innovation procurement}

According to Grant-Muller and Usher (2014) and Rainville (2018), innovation procurement (including in the field of ITS) is too often focused on efficiency and too less on finding a balance between economic and environmental benefits; thus, they seek models how ITS could contribute to positive-sum game of economic and environmental sustainability.

There are several reasons for slow take-up of agile, open and experimental methods for cities ranging from management theory (New Public Management to Value Creation, see e.g., Mantsinen et al., 2018; Matthias Weber et al., 2014; Soe and Drechsler, 2018) to public procurement best practices (see e.g., Georghiou et al., 2014; Obwegeser and Müller, 2018). Obwegeser and Müller (2018) have developed a framework of innovation 
in public procurement based on literature review (see Figure 1). According to Uyarra et al. (2014), innovation procurement has important potential to drive innovation if only the public sector could act as an intelligent and informed customer. Österberg and Qvist (2018) stress the role of public actors in steering the innovation through collaboration and competition. They found that in the case of Swedish Transport Administration, initial opening areas for innovations is followed by countermovement toward organisation: hierarchy and rules governance play key role prohibiting new innovations.

Figure 1 Innovation procurement taxonomy

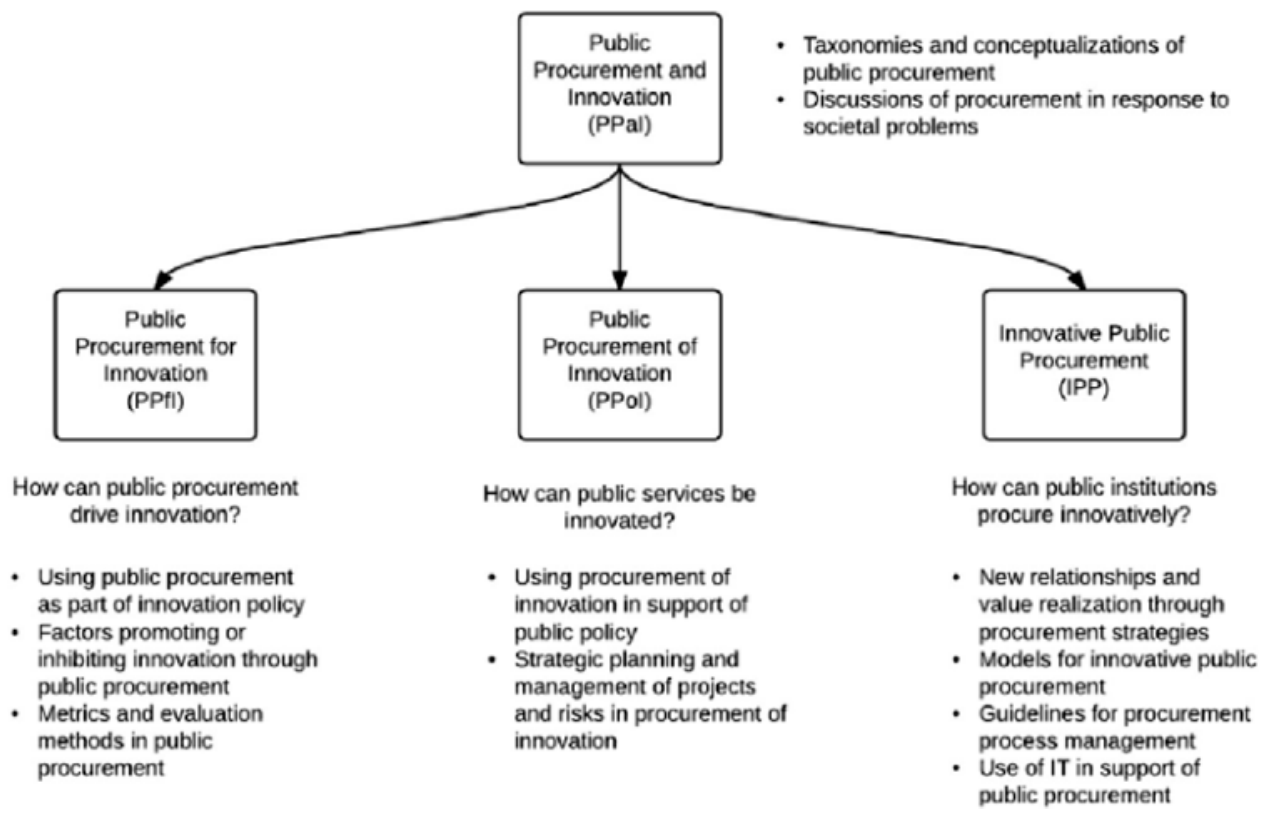

Source: Obwegeser and Müller (2018)

Georghiou et al. (2014) and Uyarra et al. (2014) surveyed hundreds of public sector suppliers in the UK and concluded that main barriers to innovation procurement are, among others, lack of ownership by purchasers, low competences on new technologies, risk aversion, limited communication between procurers and suppliers and the use of over-specified tenders. Loader (2015) has studied the UK government online feedback facility provided for the SME suppliers that see the public procurement process as frustrating and biased against them including overly prescriptive qualification criteria, poorly written tender specifications and prohibitive resource requirements. There is also some empirical evidence on the policy-practice gap in the case of Finland, where close to 100 interviews were conducted on how procures perceive policy goals and turn them into outcomes in the procurement process (Storsjö and Kachali, 2017).

Increasing number of authors (e.g., Edquist and Zabala-Iturriagagoitia, 2015; Iossa et al., 2018; Rainville, 2018) analyse pre-commercial procurement (PCP) as a factor to boost innovation and environmental sustainability in the procurement process. According to Edquist and Zabala-Iturriagagoitia (2015), PCP is a supply-side policy instrument that should be flagged as precompetitive R\&D program instead of innovation procurement instrument, although the latter is claimed to be an unsystematic method in the EU which 
should move towards life-cycle approach in order to be more coherent (Alhola and Nissinen, 2018).

\subsection{Intelligent transport systems (ITS)}

According to Sun et al. (2016), ITS connect various information, communication, sensor and control technologies and are applied to increase safety, sustainability, efficiency and comfort (see also Figure 2). ITS are seen as a key enabler of future traffic management systems; their core components include vehicles, road side units and traffic command centres; and they generate a large amount of various data, making data analytics a crucial part (Javed et al., 2019). According to Mangiaracina et al. (2017), ITS is especially necessary to deal with increasing demand for information accuracy and decision-making speed in managing the urban mobility of goods and people; ITS can provide road users with real-time information and forecast both weather and traffic.

Figure 2 Intelligent transport system (see online version for colours)

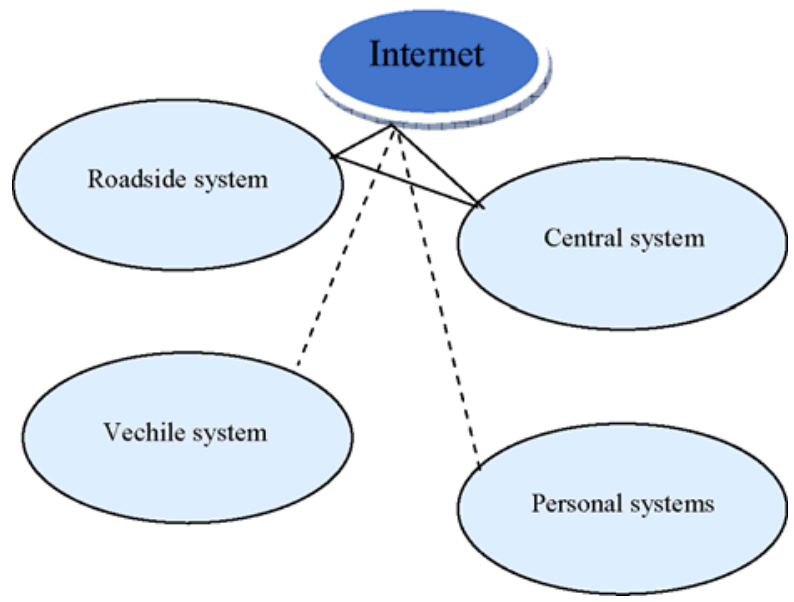

Source: Sun et al. (2016)

An important component of ITS is interaction between actors in transport systems which are enabled by means of vechile to everything (V2X) communications composed of vehicle-to-vehicle (V2V) and vehicle-to-infrastructure (V2I) (Aramrattana et al., 2019; Fouchal et al., 2017). Zhuhadar et al. (2017) see a new trend of innovation coming from humans' ability to connect to machines and the data that comes from these connections; more integrated data makes problem solving solutions available for city authorities.

Matthias Weber et al. (2014) are interested in ITS from the angle how ICT developments enable novel solutions for public transport and claim that there is a significant delay between ICTs and transport infrastructure: ICTs develop fast but they transfer to transport systems and infrastructures slowly. They point out the importance of organisational and institutional conditions for realising these ITS services; and also crucial role of entrepreneurial individuals, both in public and private sector organisations. In any case, when analysing ITS, it should be noted that it is a product of social, economic and technological development, matched with the information age (Sun et al., 2016). 


\section{Research design and methods}

The mainstream NPM as a core public administration theory tends not to work ideally in the case introducing multi-city ICT-based mobility solutions, mainly as this concept takes cities as competing silo-towers and is more focused on efficiency on single city instead of actual value added to users. Thus, this paper uses PV framework that is modified for the ITS public procurement context, based on prior work of e-government scholars (e.g., Karunasena and Deng, 2010; Kearns, 2004; Soe and Drechsler, 2018). Karunasena and Deng (2010) suggest a framework for evaluating the public values of ICT implementation in the public sector based on three drivers of public value creation:

- delivery of quality services

- $\quad$ operating effective public organisations

- achievement of socially desirable outcomes.

The conceptual framework for evaluating the PV of ITS is proposed on Figure 3.

Figure 3 The public value theoretical framework

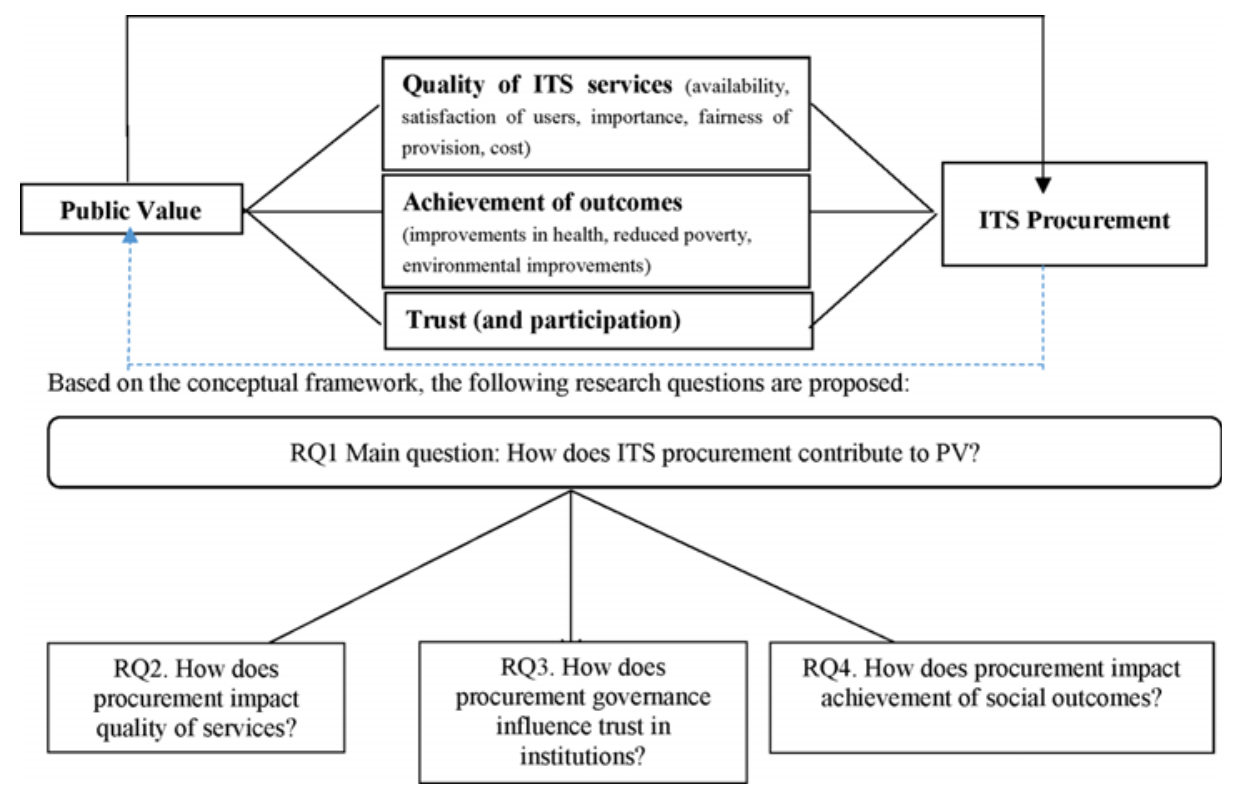

This paper analyses the set-up of cross-border pilots in Tallinn and Helsinki as part of the finest smart mobility (FESM) project, ${ }^{1}$ including the design and implementation of open and agile innovation trials as part of the procurement process. This project was selected for the following reasons:

1 it meets the PV concept in the case of ITS: open and collaborative approach

2 real-life experimentation via ITS pilots

3 cross-border international set-up makes the model replicable in other cities 
4 focus on key PV aspects: aims to improve high-demand mobility services (quality of services) and reduce $\mathrm{CO}_{2}$ emissions (achievement of social outcomes)

5 Access to recent primary and secondary data.

The FESM project deals with the connection between Helsinki West Harbor and Tallinn Old City Harbor which is one of the busiest in the world with over 8 million annual passengers. The FESM project aims to tackle this ever-increasing challenge through intelligent traffic solutions. The project provides more fluent integration of different transport modes of this inter-city and cross-border traffic with piloting and planning ICT-driven solutions. As an outcome transportation time for both passengers and cargo are expected to be reduced. The better flow of people and good results in less $\mathrm{CO}_{2}$ emission and noise in the port area as well as in the cities are expected. Through cross-border approach, end-to-end and user-centric experience are ensured and better cross-border mobility planning achieved. The project is funded through Intereg Central Baltic program (EU Structural funds) with a total budget of 1.8 million euros. Project partners are City of Helsinki, City of Tallinn, ITL Digital Lab, City of Vantaa, Estonian Road Administration and Forum Virium Helsinki.

The research method is a case study of Tallinn and greater Helsinki (cities of Helsinki, Tallinn and Vantaa) pursuing to implement digital urban transport solutions. Data was gathered through in-depth analysis of open trials via innovation procurement between the cities. Data was gathered via primary and secondary sources. The primary data include non-structured project meetings that were conducted with the city representatives (the cities of Tallinn, Helsinki and Vantaa) and companies (four ITS companies). Secondary sources include published and unpublished reports, project proposals and documents.

\subsection{Finest smart mobility project}

The FESM project was piloting smart solutions with a core goal to reduce the travel time and congestions. The project planned to improve the mobility flows arriving and leaving the Helsinki West Harbour and Tallinn Old City Harbour with a subgoal to optimise and smoothen the mobility journeys of people, public transport, private cars and trucks arriving and leaving the ports; and addresses both local and transit traffic. The FESM project was initially planning to conduct five pilots in 2017-2019:

- Pilot 1: Just-in-time logistics for heavy good vehicles, based on truck parking at the ring-roads and mobile application that directs them to the boarding. This is expected to reduce the time-in-city with an estimate of $5-10 \%$ per truck. This is also a key tool to manage the closure of the truck parking at ports.

- Pilot 2: Smart management outbound traffic, with dynamic mobility management with signage and integration to navigators and possibly to smart traffic lights. This integrates the unloading traffic to city traffic better, improving also other traffic.

- Pilot 3: Smart Park\&Ride for ferry passengers with private cars to increase the use of public transport for the port entry/exit. This includes easy real-time information and ordering of the Park\&Ride and public transport options. This is expected to reduce the number of private cars to the ports by $5 \%$. 
- Pilot 4: Smart traffic solution pilot in order to increase the modal split of public transport for travellers from Estonia to Helsinki Airport with a ferry connection.

- Pilot 5: a feasibility study with a pilot regarding the Tallinn ring-road to improve the management of both commuting and international transit traffic flows with ITS solutions.

Key roles of partners of the FESM regarding conducting pilots:

- City of Helsinki (capital of Finland) is the local authority over mobility related issues in Helsinki. City of Helsinki (Economic Development division) coordinates the whole project. City of Helsinki (City Planning Department; West Harbor Project) will provide expertise for the harbour mobility planning for the pilots. Responsible for pilots 1 and 2 .

- The city of Vantaa is the location of Helsinki Airport. Responsible for pilot 4.

- City of Tallinn (capital of Estonia) is the local authority over mobility related issues in Tallinn and consequently a partner in the project pilots. Responsible for pilot 3 , co-responsible for pilots 1 and 2 .

- Estonian Road Administration is a government agency which performs the implementation of state policy and development programs, management functions, state supervision, and applies the enforcement powers of the state in the field of road management, traffic safety, public transport and the environmental safety of vehicles. Responsible for pilot 5.

- $\quad$ Forum Virium Helsinki is a limited company fully owned by the City of Helsinki. Responsible for specifications and supporting pilots.

- The Estonian ITL Digital Lab is a non-profit and non-governmental organisation dedicated to uniting companies in the ICT sector. Responsible for supporting pilots.

\subsection{FESM tender model}

The procurements of pilots 1,2 and 4 were planned with an 'innovation challenge' type of principle, where the needs of the procurer and expected outcomes of the procurement were described, but the exact technical solution and their functionalities were supposed to be left open for the companies to plan and propose (see Table 1). The aim of the challenge-based procurement is to help the procuring authorities to find best solutions that are in the market, and on the other hand to drive the companies to propose solutions that are better targeted towards the real need of the cities and end-users. The procurement of pilots 3 and 5 were planned to follow more traditional, pre-specified and price-competition-based model.

As an example what is meant by this innovation challenge, the proposed solution, and/or parts of the proposed solution can be software, hardware, infrastructure, service or an innovative business model. As another example, for the expected outcome 
of improving the travel chain of the Estonians travelling to Helsinki Airport, the working solution could be a mobile phone application helping in the modality change pain-points, or a mobility-as-a-service type multimodal transport service tackling the same issue. However, it should be underlined that the proposed solution can also consist solely of software and hardware if the proposing company envisions that this would be the optimal way to reach the expected outcomes.

Table 1 The pilots 1, 2 and 4 executed the following call for tenders in the joint communication

\begin{tabular}{|c|c|c|c|c|}
\hline Call for tender for & $\begin{array}{l}\text { Procuring } \\
\text { authority }\end{array}$ & $\begin{array}{l}\text { Procurement } \\
\text { model }\end{array}$ & Specification & Budget \\
\hline $\begin{array}{l}\text { Pilot 1: Just-in-time and } \\
\text { queuing logistic system for } \\
\text { HGVs entering ports of } \\
\text { Helsinki and Tallinn }\end{array}$ & $\begin{array}{l}\text { Joint } \\
\text { procurement } \\
\text { with Helsinki } \\
\text { and Tallinn }\end{array}$ & $\begin{array}{l}\text { Open } \\
\text { procurement }\end{array}$ & $\begin{array}{l}\text { Functional } \\
\text { requirements } \\
\text { with outcomes } \\
\text { specification }\end{array}$ & $\begin{array}{l}162.000 € \text { (separate } \\
\text { Helsinki and } \\
\text { Tallinn budgets) }\end{array}$ \\
\hline $\begin{array}{l}\text { Pilot 2a: Open innovation } \\
\text { Partnership to support just- } \\
\text { in-time logistic system } \\
\text { implementation }\end{array}$ & Helsinki & $\begin{array}{l}\text { Innovation } \\
\text { Partnership }\end{array}$ & $\begin{array}{l}\text { Outcomes } \\
\text { specification }\end{array}$ & $\begin{array}{l}60.000 €(\text { Helsinki } \\
\text { budget) }\end{array}$ \\
\hline $\begin{array}{l}\text { Pilot } 2 \text { b: Smart management } \\
\text { of out-bound road traffic } \\
\text { when ferries have un-loaded }\end{array}$ & $\begin{array}{l}\text { Joint } \\
\text { procurement } \\
\text { with Helsinki } \\
\text { and Tallinn }\end{array}$ & $\begin{array}{l}\text { Innovation } \\
\text { partnership }\end{array}$ & $\begin{array}{l}\text { Outcomes } \\
\text { specification }\end{array}$ & $\begin{array}{l}168.000 € \text { (separate } \\
\text { Helsinki and } \\
\text { Tallinn budgets) }\end{array}$ \\
\hline $\begin{array}{l}\text { Pilot 4: Smoothening the } \\
\text { travel chain of Estonians } \\
\text { travelling to Helsinki- } \\
\text { Vantaa Airport }\end{array}$ & Vantaa & $\begin{array}{l}\text { Innovation } \\
\text { Partnership }\end{array}$ & $\begin{array}{l}\text { Outcomes } \\
\text { specification }\end{array}$ & $\begin{array}{l}90.000 € \text { (Vantaa } \\
\text { budget) }\end{array}$ \\
\hline
\end{tabular}

The proposals of this innovation challenge were evaluated from two perspectives:

First, what is the subjective value of the proposed solution for the mobility user - how the solution improves the mobility flow and mobility experience of the persons in move. The subjective value reflects how the proposed solution would deliver the change of the behaviour in real life. The expected needs of the users are described in the user profiles and specific user personas are selected for each of the pilots. Second, what is the objective value of the proposed solution for the city/transport system - how the solution improves the mobility flow from the city perspective: what is the exact reduction of the congestion, what are the potential cost savings, how the transport system would function better as a whole. This is described as expected outcomes, and detailed below for each of the pilots.

This combination of subjective and objective value in the evaluation is sometimes defined as 'value-based procurement' framework. The exact criteria were defined in detail for each of the procurements. As crude examples, the objective value could consist of reduction of the time heavy good vehicles spend in port areas, and the subjective value could consist of ability for the truck driver to know whether he/she is approaching the correct ferry in correct time to better arrange for breaks, adjust driving speed, and leaving time from previous stops. 


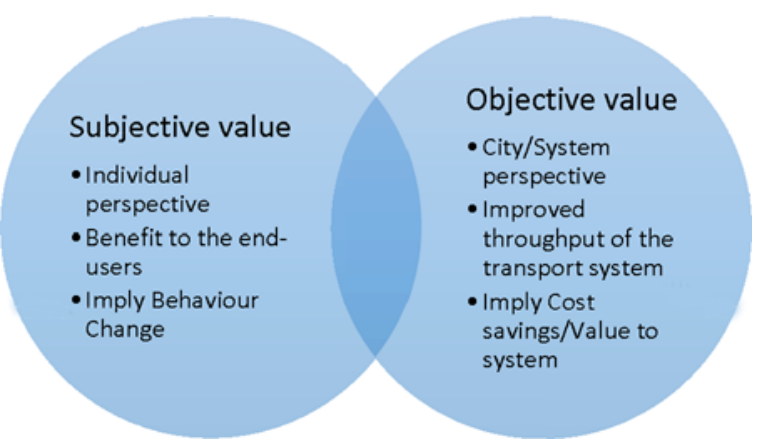

\section{$4 \quad$ Analysis and results}

The outcomes of pilots 1, 2 and 4 are described below (Sections 4.1-4.4). The pilots 3 and 5 did not realise as planned (Section 4.5), they also did not participate in the specified innovation procurement model described above.

\subsection{GoSwift: Just-in-time queuing system for truck drivers and fleet operators (Pilot 1)}

The objective of just-in-time (JIT) Queueing System for Heavy Good Vehicles (HGV) was to develop and pilot an online queuing service for HGVs when entering the old town harbours of Helsinki and Tallinn. The service aims to reduce waiting on the port parking facilities and thereby reduce traffic congestion around the harbour area of both cities. According to the pilot results, it is possible to reduce waiting time of HGVs when entering the ports when HGVs are directed to parking lots that are outside from the city-centre. The Goswift pilot guides HGVs from Tallinn to Helsinki port (only one-way) for ferry boarding taking into account road traffic, weather and estimated speed. The mobile application was developed in conjunction with the service platform that collects data on positioning and of HGVs and then guides them to the ports. The main technological functionalities of the pilots includes time-slot allocation, vehicle call, dynamic queue management, alternative waiting areas management and interfaces with ports and ferry operators. The pilot stated 1.2.2018 and run for 12 months with mobile service as an outcome on one direction (from Tallinn to Helsinki).

According to the FESM project consortium (procurer), led by the city of Helsinki, the key results were following (see Figure 4):

- timely arrival means less congestions at ports and more time for core operations

- HGV drivers not very keen to use the service (less than 100 Android installations)

- on-spot marketing increased the number of pilot drivers

- the solution could benefit from the remote check in option

The service is still available and marketed in the port of Tallinn (as of in April/May 2019). Key resources and links (links available dependent on the pilot continuation):

- Mobile service: https://finest.goswift.eu/web/index 
Figure 4 GoSwift pilot service (see online version for colours)

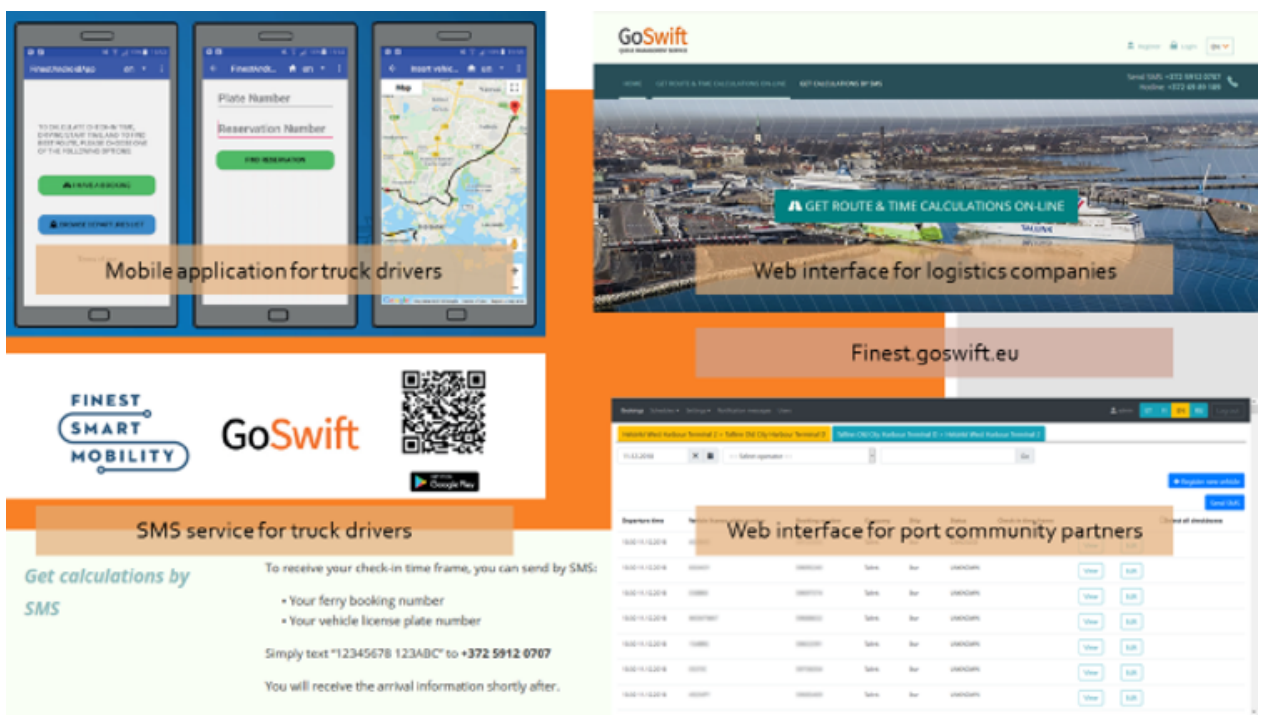

\subsection{Infotripla: predictive traffic management (Pilot 2)}

Infotripla developed and piloted a traffic fluency model based on open data and analytics, provided dashboard and twitter alerts for traffic management that includes video bridge to predefined areas and routing suggestions. The pilot is monitoring and predicting existing traffic situation around the Helsinki West Harbour (where main connection is with the Tallinn Old Port) and provides information on traffic situation and predicts traffic in short term. The concept labelled Harbour's Predicted and Smooth Outbound Traffic (Harbour's PSO) is based on traffic data analytics system and developed further into harbour traffic information system (see Figure 5). The priority of this concept is to analyse and model the traffic situation, traffic predictions and traffic incident alerts ('black box' on the figure).

This pilot aimed to integrate several data sources of intelligent traffic infrastructure to provide traffic fluency model, aggregated on cloud (TDAC - traffic data analysis cloud). In addition to road-specific data, the pilot also used ferry related data provided by Fleetrange' pilot that estimates time of arrival (ETA) for ferries (although initially the PortNet system was planned). Traffic information was delivered via information delivery stack: Event visualisation (responsive web), Event delivery interface (standardised Datex2), Incident alerts and routing information via social media channel (Twitter) and Routing suggestions via web application (web based information service or application).

According to the FESM project consortium (procurer), led by the City of Helsinki, the results were following (see also Figure 6):

- improved reactivity of traffic management

- modularity of the service improves scalability

- open data for other developers (traffic incidents, roadworks, route suggestions). 
Figure 5 The pilot service stack of Infotripla (see online version for colours)

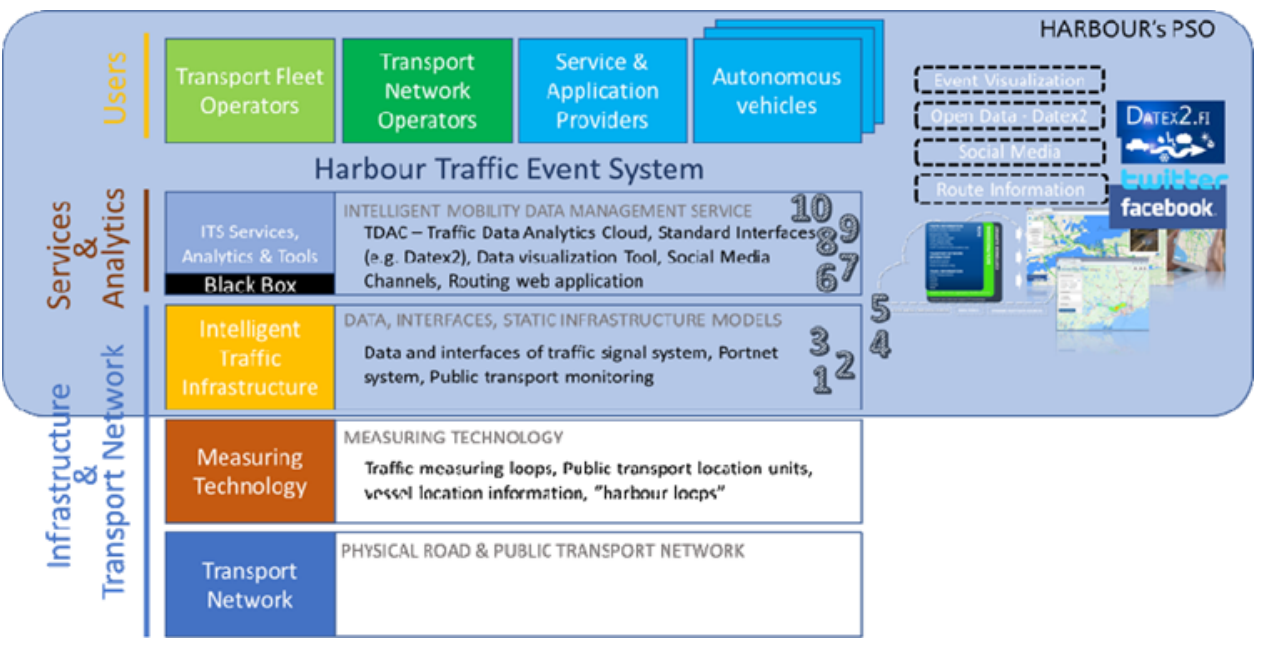

Figure 6 The outcome of the Infotripla pilot (see online version for colours)

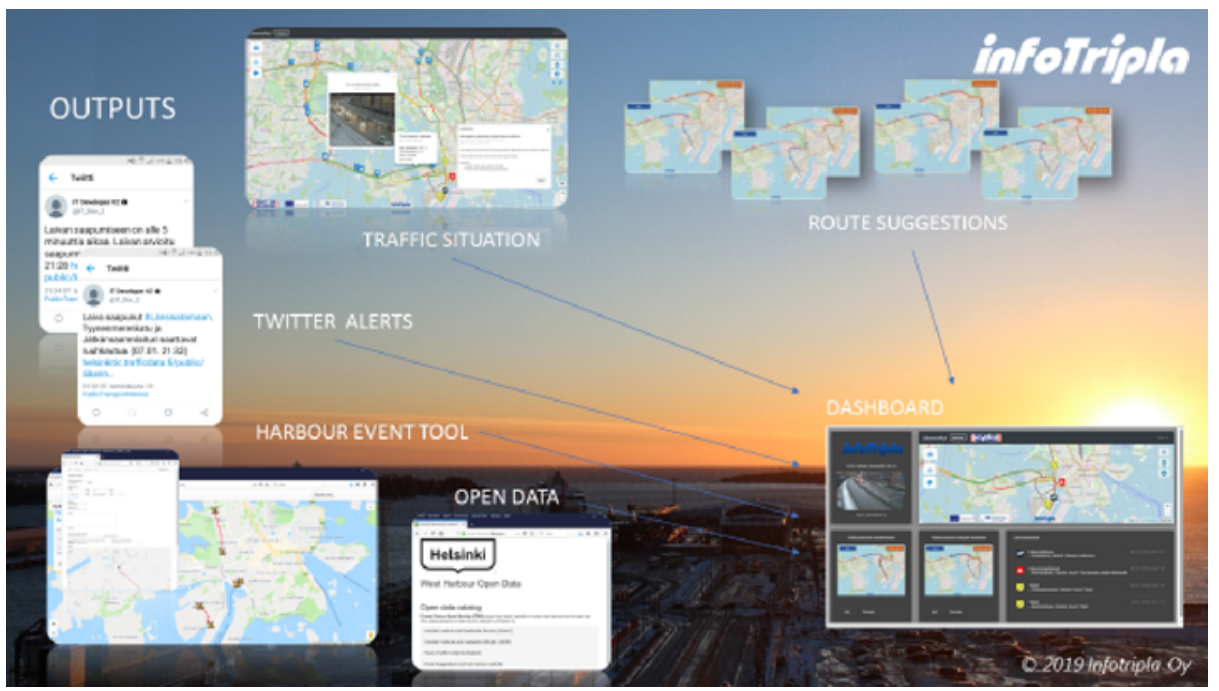

In the next stage, this pilot is expected to continue as part of the Jätkasaari Mobility Lab that also includes traffic lights data. Ideally, it also can be piloted in other harbours, starting with Tallinn Old Harbour. Key resources and links (links available dependent on the pilot continuation):

- dashboard's address: https://helsinki.dashboard.liikennenyt.fi

- traffic snapshot: https://helsinki.liikennenyt.fi

- route suggestions: https://helsinki.liikennenyt.fi/opendata/index.html

- harbour event tool: https://helsinkitic.trafficdata.fi

- $\quad$ open data: https://helsinki.liikennenyt.fi/opendata/index.html 


\subsection{Fleetrange: real-time ferry position and arrival info (Pilot 2)}

The Fleetrange pilot provides automated and real-time schedule tracking of ferry traffic between the West Harbor in Helsinki and the Old Port of Tallinn via easy-access one-stop-shop. This is executed via a real-time application programming interface (API) service available for other service providers or application developers, the cities' infrastructure systems, ports, traffic lights, taxi services, ferry companies and others. According to the initial architecture (Figure 7), the geofencing model for tracking was dropped during development and substituted with a route/location based calculation. The API is built as a node.js server application, which reads data from Digitraffic, FMI and websites. The server calculates real-time estimated time arrival (ETA) and gives access to up-to-date tracking, schedule, weather and ETA data in programmatic format. All components and data is open source or Open Data. The tracking data ( $\sim 14$ million data points and $\sim 4000$ voyages) was collected during the period May-Oct 2018; and also Feb 2019; this has given a proper dataset for further research into the ETA prediction techniques. The real- time and open API has been reliable, with some minor development related challenges in July (software bug) and October (crash). According to the results, the ferry tracking between Tallinn and Helsinki shows a high schedule accuracy ( -3 minutes of delay on average) for the ferries on this route (although departure times are less accurate: -9 minutes on average).

Figure 7 Fleetrange pilot API original plan (see online version for colours)

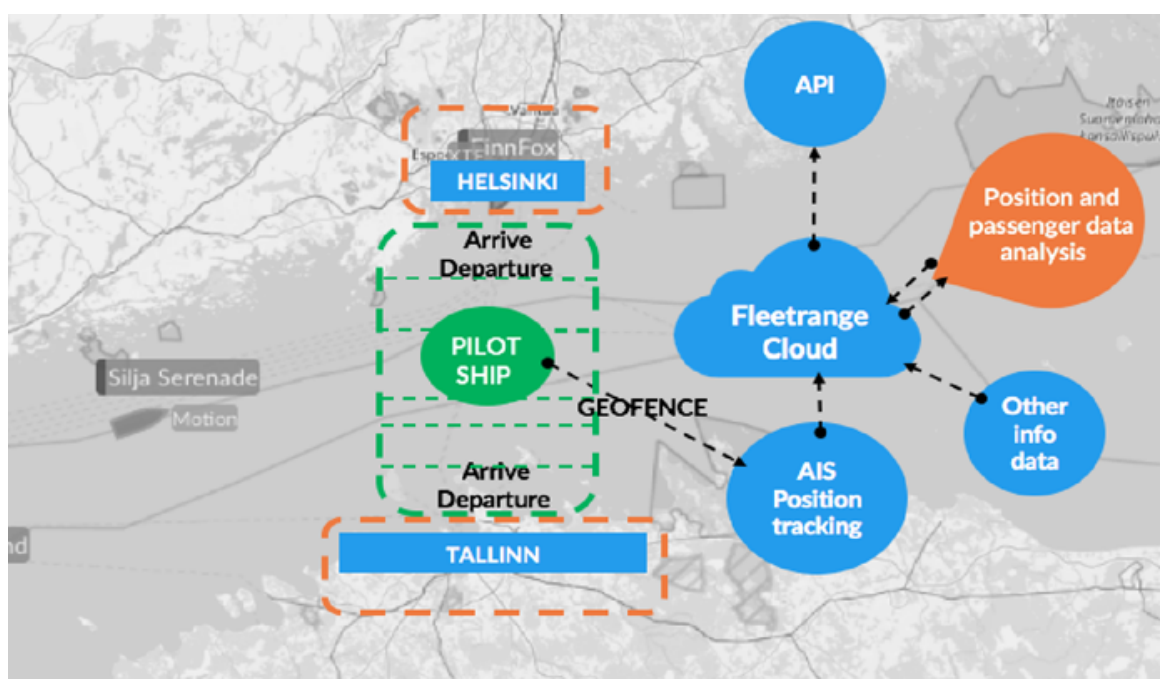

According to the FESM project consortium (procurer), led by the City of Helsinki, the key results were following (see Figure 8):

- $\quad$ proper ferry statistics

- $\quad$ punctual traffic during piloting, most differential takes place during docking

- $\quad$ allows integration of ferry schedules to other services (e.g., Ampron Led display)

- not operational anymore but data available on Helsinki Region Infoshare. 
Key resources and links (links available dependent on the pilot continuation):

- FESM API: https://fleetrange.com/finestapi

- licences and data sources: https://finestapi.fleetrangelive.com/docs/\#/

Figure 8 Fleetrange pilot dashboard and core statistics (see online version for colours)
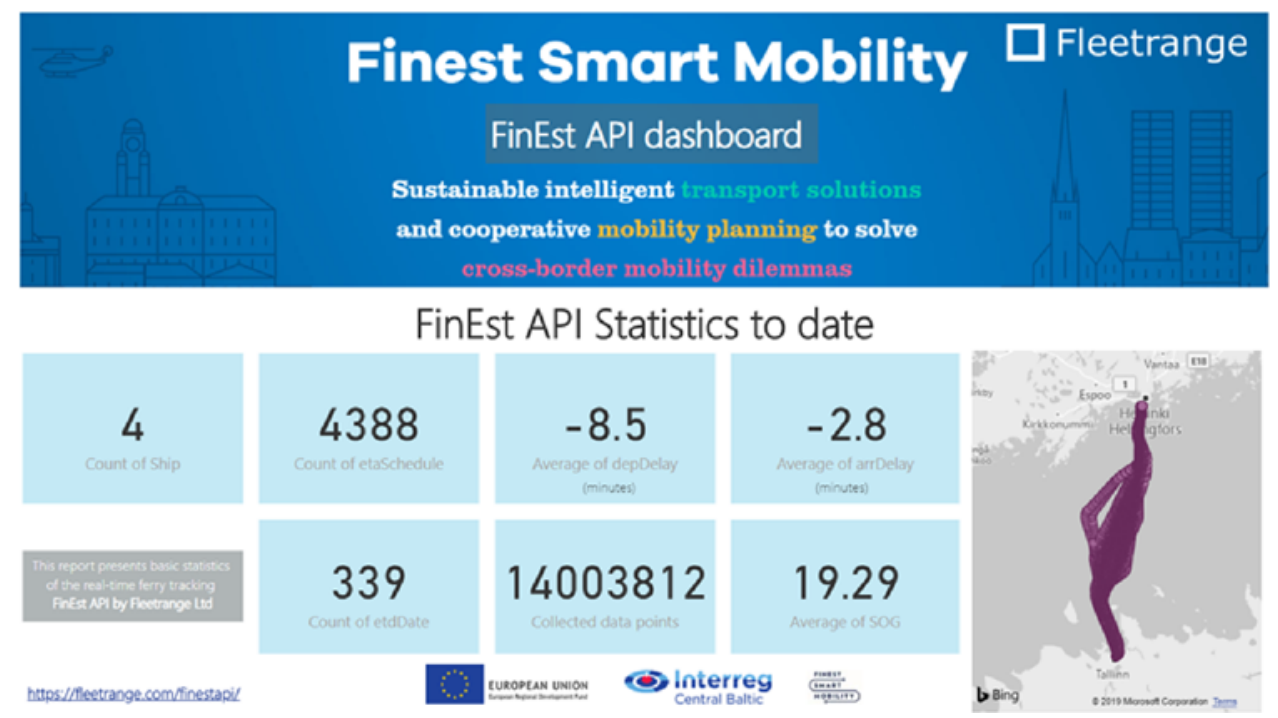

\subsection{Kyyti: Shared taxi to Helsinki Airport (PILOT 4)}

This pilots delivered a shared taxi service (Kyyti Kimpaa) that was launched 21.09.2018 based on the Kyyti mobility as a service (MaaS) platform (see Figure 9) that aims to integrate urban transit, intercity buses, trains, car rental \& sharing and payments \& ticketing options. This platform already included public transport, walking and cycling route planners prior the pilot. Kyyti on-demand ride sharing is based on automated fleet management and dynamic pricing. The mobility data modelling and simulation capabilities can reveal (if there are critical amount of users) how people move. During the pilot (from 21 September to 12 December) in Helsinki region, there were 148 Kyyti trips with 251 passengers of which: three trips were made to West Harbor; two trips from West Harbor and two trips to the Airport. As seen, this pilot did not attract users travelling between West Harbor and the airport; trips from/to West Harbor were not popular either.

\subsection{Park and ride and ringroad (Pilots 3 and 5)}

The initial plan was to develop a cross-border Smart P\&R solution in close cooperation with cities (Tallinn and Helsinki), public transport and /or ticketing operators (e.g., Ridango and Helsinki Regional Transport) by linking Park\&Ride and public transport data between Tallinn and Helsinki in order to develop an interoperable Park and Ride service. Unfortunately, this idea was too challenging for the Tallinn public transport and smart parking validation company Ridango and also legally too challenging for the Helsinki Region Transport. 
Figure 9 Kyyti platform (see online version for colours)

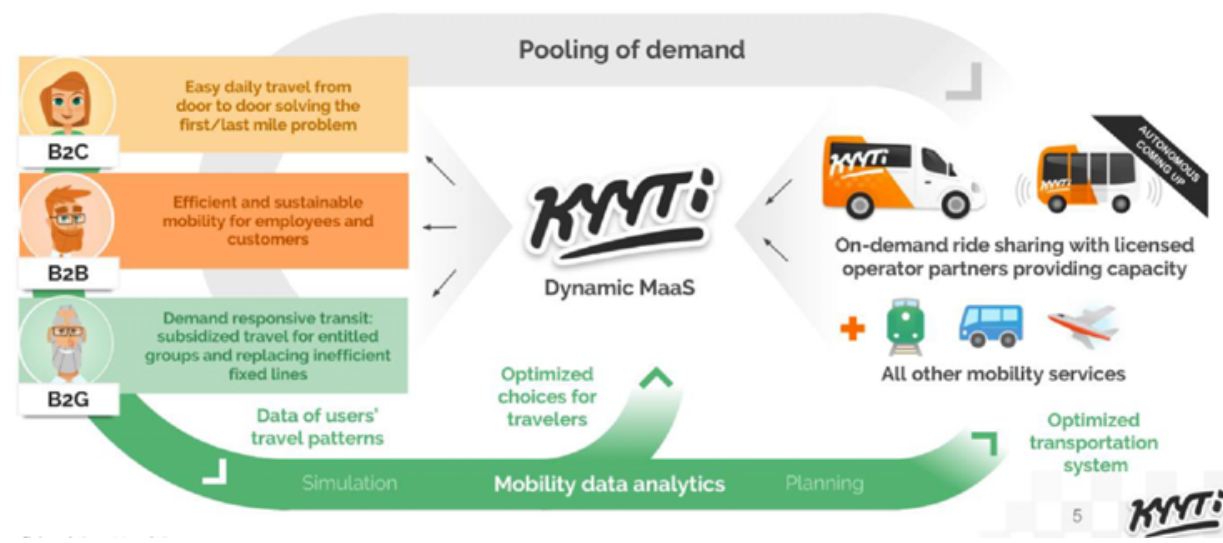

Therefore, after one year of developing this plan and discussions with important stakeholders (2017-2018), the approach was to run this as a cross-border innovation competition, similarly to pilots 1 and 2 . When seeking alternatives to organise 'innovation partnership' tendering process, the City of Tallinn faced internally lack of experience to organise Innovation trials. After discussions with city procurement experts, this led to situation, where the WP T3 'Smart P\&R' was facing delays in actions. Over the summer of 2018, the City of Tallinn jointly with the ITL Digital Lab, developed an innovation contest proposal which was rejected by the procurement experts of the city of Tallinn. The main challenge is that the City of Tallinn lacks experience in running non-price-related competitions (excluding architectural ones).

The ringroad pilot did not match the investment plans of the Road Administrations so it was decided to perform it independently from this project. Partially, this approach was tested in the pilot 1.

\section{Conclusions}

When planning and conducting ICT-based mobility trials, the value added for citizens should be considered as a key principle and methodically, more agile and adoptive solutions could be implemented. In the case of multi-city approach, the NPM, rooted in protecting a single city interest without agile and open toolbox, seems not to be the best solution, at least theoretically. Thus, this paper proposes PV theory instead for multi-city mobility innovation experiments that also support more participatory innovation procurement. The PV is not drawing strict borders between the regions but is focused on cooperation and openness instead: this is very important in the case of observed cities of Helsinki, Tallinn and Vantaa as a significant share of population is regularly commuting.

It is rather early to evaluate the outcomes of pilots as they were finalised at the time of writing this paper. It is clear that innovation process in general is risky and the userperspective outcomes cannot always be predicted. In most cases, the pilots did not attract as many critical users as they were wishing but take-up rates are not linear. In terms of innovation procurement, this paper tends to argue that pilots 1 and 2 that were designed as an open partnership model, tend to be more successful in the case of adopting more 
experimental mobility innovation solutions (see Table 2). The pilot 3 started as traditional procurement model and then had internal difficulties to be redesigned as an open partnership approach and later failed as traditional procurement model, mainly because of its complexity and the fact that it was not planned as innovation procurement from a scratch. The pilot 4 can be seen somewhere between of PV and NPM, while pilot 5, rather designed from the NPM logic, cannot be evaluated as it was not implemented at all, although it was supposed to follow the traditional procurement model.

Table 2 Agile trials (PV) vs. traditional approach (NPM)

\begin{tabular}{|c|c|c|}
\hline & Open $(P V) /$ pilots 1,2 & Traditional (NPM)/pilot 3 \\
\hline Level of centralisation & Bottom-up, decentralised & Top-down, centralised \\
\hline Level of technology & Up-to-date & Time-lagged \\
\hline Involvement of stakeholders & Open approach & Closed approach \\
\hline \multicolumn{3}{|l|}{ Public value added in... } \\
\hline ...quality of services & High & Medium \\
\hline ....achievement of outcomes & High & Medium \\
\hline ...trust in institutions & Medium to High & Low to Medium \\
\hline
\end{tabular}

The main research question (RQ1) was interested how public procurement contributes to public value and it was replied by three sub-questions. The sub-questions were focused on the interplay between innovation procurement and three domains of PV: quality of services, trust in institutions and achievement of social outcomes. These questions were analysed via recent empirical evidence in the case of cities of Helsinki, Tallinn and Vantaa. As the results of this particular case study, city governments can effectively improve the design of mobility services (quality of services - Research Question 2), reduce $\mathrm{CO}_{2}$ emissions (achievement social outcomes - Research Question 3), and create trust in institutions (Research Question 4) while at the same time being adaptive and agile (PV approach). On the other hand, NPM tends to be centralised, delayed, with closed stakeholders and too limited outcomes in the case of more experimental pilots.

\section{Acknowledgements}

This work has been supported by the European Commission through the Baltic Sea Interreg project Finest Smart Mobility (CB359) and the H2020 project Finest Twins (grant No. 856602). It is also linked to the following projects: TalTechCity (funded by City of Tallinn and Tallinn University of Technology) and Cap4City (co-financed by the European Commission via Erasmus +).

\section{References}

Alhola, K. and Nissinen, A. (2018) 'Integrating cleantech into innovative public procurement process - evidence and success factors', Journal of Public Procurement, Vol. 18, No. 4, pp.336-354, https://doi.org/10.1108/JOPP-11-2018-020 
Aramrattana, M., Larsson, T., Jansson, J. and Nåbo, A. (2019) 'A simulation framework for cooperative intelligent transport systems testing and evaluation', Transportation Research Part F: Traffic Psychology and Behaviour, Vol. 61, pp.268-280, https://doi.org/ 10.1016/j.trf.2017.08.004

Cordella, A. and Bonina, C.M. (2012) 'A public value perspective for ICT enabled public sector reforms: a theoretical reflection', Government Information Quarterly, Vol. 29, No. 4, pp.512-520, https://doi.org/10.1016/j.giq.2012.03.004

Edquist, C. and Zabala-Iturriagagoitia, J.M. (2015) 'Pre-commercial procurement: a demand or supply policy instrument in relation to innovation?', $R$ and D Management, Vol. 45, No. 2, pp.147-160, https://doi.org/10.1111/radm.12057

Fouchal, H., Bourdy, E., Wilhelm, G. and Ayaida, M. (2017) 'A validation tool for cooperative intelligent transport systems', Journal of Computational Science, Vol. 22, pp.283-288, https://doi.org/10.1016/j.jocs.2017.05.026

Georghiou, L., Edler, J., Uyarra, E. and Yeow, J. (2014) 'Policy instruments for public procurement of innovation: choice, design and assessment', Technological Forecasting and Social Change, Vol. 86, pp.1-12, https://doi.org/10.1016/j.techfore.2013.09.018

Grant-Muller, S. and Usher, M. (2014) 'Intelligent transport systems: the propensity for environmental and economic benefits', Technological Forecasting and Social Change, Vol. 82, No. 1, pp.149-166, https://doi.org/10.1016/j.techfore.2013.06.010

Iossa, E., Biagi, F. and Valbonesi, P. (2018) 'Pre-commercial procurement, procurement of innovative solutions and innovation partnerships in the EU: rationale and strategy', Economics of Innovation and New Technology, Vol. 27, No. 8, pp.752-771, https://doi.org/ $10.1080 / 10438599.2017 .1402431$

Janssen, M. and van der Voort, H. (2016) 'Adaptive governance: towards a stable, accountable and responsive government', Government Information Quarterly, Vol. 33, No. 1, pp.1-5, https://doi.org/10.1016/j.giq.2016.02.003

Javed, M.A., Zeadally, S. and Hamida, E.B. (2019) 'Data analytics for cooperative intelligent transport systems', Vehicular Communications, Vol. 15, pp.63-72, https://doi.org/10.1016/ j.vehcom.2018.10.004

Karunasena, K. and Deng, H. (2010) 'Exploring the public value of e-government: an empirical study from Sri Lanka', Proceedings of Bled eConference eTrust: Implications for the Individuals. Enterprises and Society 2010, Bled, Slovenia, pp.286-300.

Kearns, I. (2004) Public Value and E-government, Retrieved from http://www.centreforcities.org/ assets/files/pdfs/public_value_egovernment.pdf

Loader, K. (2015) 'SME suppliers and the challenge of public procurement: Evidence revealed by a UK government online feedback facility', Journal of Purchasing and Supply Management, Vol. 21, No. 2, pp.103-112, https://doi.org/10.1016/j.pursup.2014.12.003

Mangiaracina, R., Perego, A., Salvadori, G. and Tumino, A. (2017) 'A comprehensive view of intelligent transport systems for urban smart mobility', International Journal of Logistics Research and Applications, Vol. 20, No. 1, pp.39-52. https://doi.org/10.1080/ 13675567.2016.1241220

Mantsinen, H., Hinkka, V., Hautala, R., Leviäkangas, P. and Aapaoja, A. (2018) 'The Finnish road weather business ecosystem - structure, potentials and implications for demand-driven innovation policy', International Journal of Services Sciences, Vol. 6, Nos. 3-4, p.179, https://doi.org/10.1504/ijssci.2017.10013044

Matthias Weber, K., Heller-Schuh, B., Godoe, H. and Roeste, R. (2014) 'ICT-enabled system innovations in public services: experiences from intelligent transport systems', Telecommunications Policy, Vol. 38, Nos. 5-6, pp.539-557, https://doi.org/10.1016/ j.telpol.2013.12.004

Moore, M.H. (1995) Creating Public Value: Strategic Management in Government,Harvard University Press, Cambridge, MA. 
Nuottila, J., Aaltonen, K. and Kujala, J. (2016) 'Challenges of adopting agile methods in a public organization', International Journal of Information Systems and Project Management, Vol. 4, No. 3, pp.1608-1626, https://doi.org/10.1108/ijmpb-06-2016-0054

Obwegeser, N. and Müller, S.D. (2018) 'Innovation and public procurement: terminology, concepts, and applications', Technovation, Vols. 74-75, February, pp.1-17, https://doi.org/ 10.1016/j.technovation.2018.02.015

Österberg, E.E. and Qvist, M. (2018) 'Public sector innovation as governance reform: a comparative analysis of competitive and collaborative strategies in the swedish transport sector', Administration and Society, https://doi.org/10.1177/0095399718789077

Rainville, A. (2018) 'Standards in green public procurement - a framework to enhance innovation', Journal of Cleaner Production, Vol. 167, No. 2017, pp.1029-1037, https://doi.org/10.1016/ j.jclepro.2016.10.088

Soe, R-M. (2017a) 'FINEST twins: platform for cross-border smart city solutions', in Hinnant, C.C. and Ojo, A. (Eds.): dg.o '17: Proceedings of the 18th Annual International Conference on Digital Government Research, Association for Computing Machinery (ACM), New York, pp.352-357, doi: 10.1145/3085228.3085287

Soe, R-M. (2017b) 'Smart cities: from silos to cross-border approach', International Journal of E-Planning Reasearch, Vol. 7, No. 2, pp.687-724, https://doi.org/10.1201/9781351228480

Soe, R-M. (2017c) 'Smart twin cities via urban operating system', ICEGOV '17, 7-9 March, 2017, New Delhi, India, pp.391-400, https://doi.org/10.1145/3047273.3047322

Soe, R.M. and Drechsler, W. (2018) 'Agile local governments: experimentation before implementation', Government Information Quarterly, Vol. 35, No. 2, pp.323-335, https://doi.org/10.1016/j.giq.2017.11.010

Storsjö, I.T. and Kachali, H. (2017) 'Public procurement for innovation and civil preparedness: a policy-practice gap', International Journal of Public Sector Management, Vol. 30, No. 4, pp.342-356, https://doi.org/10.1108/IJPSM-10-2016-0177

Sun, L., Li, Y. and Gao, J. (2016) 'Architecture and application research of cooperative intelligent transport systems', Procedia Engineering, Vol. 137, pp.747-753, https://doi.org/10.1016/ j.proeng.2016.01.312

Uyarra, E., Edler, J., Garcia-Estevez, J., Georghiou, L. and Yeow, J. (2014) 'Barriers to innovation through public procurement: a supplier perspective', Technovation, Vol. 34, No. 10, pp.631-645, https://doi.org/10.1016/j.technovation.2014.04.003

Yildiz, M. (2007) 'E-government research: reviewing the literature, limitations, and ways forward', Government Information Quarterly, Vol. 24, No. 3, pp.646-665, https://doi.org/ 10.1016/j.giq.2007.01.002

$\mathrm{Yu}, \mathrm{C}-\mathrm{C}$. (2008) 'Building a value-centric e-government service framework based on a business model perspective', in Wimmer, M.A., Scholl, H.J. and Ferro, E. (Eds.): Electronic Government. EGOV 2008, Lecture Notes in Computer Science. 5184, Springer, Berlin, Heidelberg.

Zhuhadar, L., Thrasher, E., Marklin, S. and de Pablos, P.O. (2017) 'The next wave of innovation review of smart cities intelligent operation systems', Computers in Human Behavior, Vol. 66, pp.273-281, https://doi.org/10.1016/j.chb.2016.09.030

\section{Note}

${ }^{1}$ www.finestsmartmobility.com 